\title{
Phenotypic and genetic parameters of milk yield traits in first-calf heifers of Holstein-Friesian breed
}

\author{
Mladen Popovac ${ }^{1 *}$, Aleksandar Miletić2 ${ }^{2}$ Nikola Raguž³ \\ Radmila Beskorovajni ${ }^{4}$, Dragan Stanojević ${ }^{1}$, Mihailo Radivojević ${ }^{2}$, \\ Nenad Mićić ${ }^{5}$ Nenad Đurić 6
}

\footnotetext{
1 University of Belgrade, Faculty of Agriculture, Nemanjina 6, 11080 Zemun, Serbia

${ }^{2}$ Intitute PKB Agroeconomik, Industrijsko naselje bb, 11000 Belgrade, Serbia

${ }^{3}$ Josip Juraj Strossmayer University of Osijek, Faculty of Agriculture, Kralja Petra Svačića 1d, 31000 Osijek, Croatia

${ }^{4}$ Institute for Science Application in Agriculture, Bulevar despota Stefana 68b, 11000 Belgrade, Serbia

${ }^{5}$ Institute for Animal Husbandry Belgrade, Autoput 16, 11000 Belgrade, Serbia

${ }^{6}$ John Naisbitt University, Faculty for Biopharming, Maršala Tita 39, 21400 Bačka Palanka, Serbia

*Corresponding author: E-mail: mlp@agrif.bg.ac.rs
}

\section{Abstract}

The objective of this paper was to study variability, heritability and correlation of the three production traits in 1409 first-calf heifers of Holstein-Friesian breed; including the determination of the quantity of milk during lactation (ML), the quantity of milk fat during lactation (MM) and the quantity of protein during lactation (PR). According to the obtained results it could be concluded that there were statistically significant differences ( $P<0.01, P<0.05, P<0.001$ ) between $M L, M M$ and $P R$ regarding the effect of season of the first calving and the length of the first lactation. In addition, there were also significant differences $(P<0.01, P<0.001)$ between $M L$ and $P R$ with respect to the effect of farm on which animals were raised, while on MM variability the year and age at first calving had a significant effect $(P<0.05)$. A share of Holstein genes and the ration which animals were fed had no effect $(P>0.05)$ on variability of any of the examined traits, while the farm on which animals were raised had no effect $(P>0.05)$ on $M M$, and year and age at first calving did not demonstrate $(P>0.05)$ statistically significant effect on $M L$ and PR. By applying the animal model, based on the use of kinship matrix which involved 3867 animals, by help of REML methodology following heritability coefficients were evaluated: $M L h^{2}=0.25 ; M M h^{2}=0.40$; $P R h^{2}=0.37$. Coefficients determined for genetic and phenotypic correlations indicated existence of complete and positive correlations between these traits the interval of values being from $r_{g}=0.96$ between $\mathrm{ML}$ and $\mathrm{MM}$ to $\mathrm{r}_{\mathrm{g}}=1.00$ between $\mathrm{ML}$ and $\mathrm{PR}$.

Key words: Holstein-Friesian first-calf heifers, cow milk yield traits, animal model, heritability, genetic correlations 


\section{Introduction}

Observing the production characteristics among different populations of Black and White dairy cattle, it is evident that a significant progress was made over the past few decades in this group of traits and that in some populations these traits, on domestic and global level as well, reached almost biological maximum regarding their realised performance. On the other hand, there are cow populations with highly expressed variability of production traits characterized by great differences in production among different animals. Those populations actually represent a "polygon" for application of suitable modern breeding and selection programmes which aim to improve the production traits of the animals in such populations. However, in genetically superior dairy cattle populations a focus of selection work is nowadays more and more put on the traits of longevity and the functional traits in cows (Raguž et al., 2014).

The selection process of domestic animals is a very delicate and it's success in many ways dependant on the accuracy of the evaluated genetic and phenotypic parameters which were regarded as a basis for the conducted selection (Popovac et al., 2014), and which are necessary for estimating the breeding performance of domestic animals for certain kind of production by means of some reference methods (selection index, BLUP). One of the major conditions when researching variability and improving the traits is to recognize and analyse non-genetic and genetic effects essential for manifestation of traits in order that determined coefficients of heritability should be representative parameters of the share of hereditary factor in realisation of the traits.

When considering the cow production traits such as quantity of milk, milk fat and protein, the largest number of available literature references report their mean heritability (Kheirabadi et al., 2013; Konig et al., 2005; Elzo et al., 2004; Waller and Ezra, 2004; Boujenane, 2002), where heritability coefficients in largest number of cases are ranging from 0.20 to 0.40 . Accordingly, there has been a considerable genetic progress has been for these traits over the previous period. In contrast to the above mentioned statements, fewer studies report a low heritability of the mentioned traits determined within certain cow populations (Stanojević et al., 2012b; Palacios et al., 2007; Lagar et al., 2005).

\section{Material and method}

The trial included production data of 1409 firstcalf heifers of Holstein-Friesian breed raised on two farms of the "PKB Corporation" in Serbia, which were first calved in the period from 2012 to 2014. Variability and correlation of the three production traits realised in first lactation, namely the total quantity of milk during lactation (ML), the total quantity of milk fat during lactation (MM) and the total quantity of protein during lactation (PR) were studied in these animals.

The process of preparation of data analysis was conducted applying the "step by step" principle. Firstly, within a "SAS/STAT" programme package (SAS Inst. Inc., 2010) a systemic part of model (Model 1) was analysed by GLM procedure, by least squares methodology involving fixed and regression effects presumed according to previous experience and biological justification to being able to exert some influence on analysed traits.

MODEL 1.

$$
\begin{gathered}
Y_{i j k l m}=\mu+F_{i}+H_{j}+O_{k}+S_{1}+C_{m} \\
+b_{1}\left(x_{i j k l m}-\bar{x}\right)+b_{2}\left(x_{i j k l m}-\bar{x}\right)+e_{i j k l m}
\end{gathered}
$$

Where: $Y_{\mathrm{ijk} k m}$ - is manifestation of the observed trait of I individual, $\mu$ - general average of the observed trait in a population, $F_{i}$ - farm on which the first-calf hiefers were raised $(i=1,2), H_{j}$ - share of Holstein genes in first-calf heifers $(j=1,2, \ldots 25)$, $\mathrm{O}_{\mathrm{k}}$ - ration composition which animals received in a preparation period ( $k=1,2, \ldots 4), S_{\text {I }}$ - season of first calving defined as three-month period $(I=1,2, \ldots 4)$, $G_{m}$ - year of first calving $(m=1,2,3), b_{1}\left(x_{i j k l m}-\bar{x}\right)$ - regression effect of age at calving, $b_{2}\left(x_{i j k l m}-\bar{x}\right)$ regression effect of duration of lactation, $e_{i j k l m}$ - the effect of undetermined factors (the rest).

The next step was to make a kinship matrix on the basis of which precise genetic relations between animals would be determined in order to include an animal effect into a mixed model on the basis of which, by means of REML procedure, an animal direct additive effect in manifestation 
of analysed traits was evaluated. Checking the accuracy of genetic correlations in kinship matrix was performed within a Pedigree Viewer 6.5 programme package (Kinghorn, 1994) by which it was determined that kinship matrix contains 3867 animals in total. Next, the evaluation of variances and covariances was performed in the "VCE - 6" programme package (Groeneveld et al., 2010), while the preparation of data for analysis was performed as previously mentioned and data coding was done by the "PEST" programme package (Groeneveld et al., 1990). The mixed multi-trait models which served as the basis for analysis of variances and covariances between the examined traits contained besides animal random additive effect also all those systemic effects which were previously determined to demonstrate statistically significant effect on the variability of studied traits, regardless of the significance level. Thus two mixed models were constructed - model 2 for $\mathrm{ML}$ and PR, and model 3 for MM.

MODEL 2. (ML, PR)

$$
Y_{i j k}=\mu+F_{i}+S_{j}+b_{1}\left(x_{i j k}-\bar{x}\right)+a_{i j k}+e_{i j k}
$$

Where: $Y_{i j k}$ - is the manifestation of the studied trait of $I$ individual, $\mu$ - general average of the studied trait in population, $F_{i}$ - farm on which the first-calf heifers were raised $(i=1,2), S_{j}$ - season of the first calving defined as a three-month period ( $\mathrm{j}$ $=1,2, \ldots 4), b_{1}\left(x_{i j k}-\bar{x}\right)$ - regression effect of the duration of lactation, $\mathrm{a}_{\mathrm{ijk}}$ - animal direct additive genetic effect (breeding performance), $\mathrm{e}_{\mathrm{ijk}}$ - effect of undetermined factors (the rest).

MODEL 3. (MM)

$$
Y_{i j k}=\mu+S_{i}+G_{j}+b_{1}\left(x_{i j k}-\bar{x}\right)+b_{2}\left(x_{i j k}-\bar{x}\right)+a_{k}+e_{i j k}
$$

Where: $Y_{\mathrm{ijk}}$ - is the manifestation of studied trait of I individual, $\mu$ - general average of observed trait in population, $S_{i}$ - season of first calving defined as three-month period $(i=1,2, \ldots 4), G_{j}$ - year of first calving $(j=1,2,3), b_{1}\left(x_{i j k}-\bar{x}\right)$ - regression effect of age at calving, $b_{2}\left(x_{i j}-\bar{x}\right)$ - regression effect of duration of lactation, $\mathrm{a}_{\mathrm{ijk}}$ - animal direct additive genetic effect (breeding performance), $e_{i j k}$ - the effect of undetermined factors (the rest).
Heritability coefficient (heritability) of analysed traits was presented as a relationship of additive genetic variance and total phenotypic variance expressed by following expression:

$$
h^{2}=\frac{\sigma_{a}^{2}}{\sigma_{p h}^{2}}
$$

Where: $\mathrm{h}^{2}$ - is a heritability coefficient (heritability), - additive genetic variance, - total phenotypic variance.

Coefficients of phenotypic and genetic correlations were calculated on the basis of following expressions:

$$
r_{\text {phXY }}=\frac{\left(\operatorname{Cov}_{\text {phXY }}\right)}{\sqrt{\sigma_{\text {phX }}^{2}+\sigma_{\text {phY }}^{2}}} \quad r_{g X Y}=\frac{\left(\operatorname{Cov}_{g X Y}\right)}{\sqrt{\sigma_{g X}^{2}+\sigma_{g Y}^{2}}}
$$

Where: $r_{\text {phXY }}$ - is a coefficient of phenotypic correlation between $X$ and $Y$ traits, $\operatorname{Cov}_{\text {phXY }}$ - phenotypic covariance between $X$ and $Y$ traits, - phenotypic variance of $X$ trait, - phenotypic variance of $Y$ trait, $r_{g X Y}$ - coefficient of genetic correlation between $X$ and $Y$ traits, $\operatorname{Cov}_{g X Y}$ - genetic covariance between $X$ and $Y$ traits, - genetic variance of $X$ trait, - genetic variance of $Y$ trait.

The traits correlation strength was determined on the basis of Roemer-Orphal classification (Latinović, 1996). Statistical significance of correlation coefficients was determined on the basis of tables of statistical significance developed by Snidikor and Cochran (1971).

\section{Results and discussion}

First-calf heifers of Holstein-Friesian breed raised on the PKB Corporation farms and calved in the period from 2012 to 2014, realised an average dairy production in all lactations of $9852.74 \pm 2055.85 \mathrm{~kg}$, with $349.54 \pm 68.94 \mathrm{~kg}$ milk fat and $317.11 \pm 64.50 \mathrm{~kg}$ protein (Table 1). 
TABLE 1. Descriptive statistical parameters for milk yield traits in first-calf heifers

\begin{tabular}{l|l|l|l|l|l|l}
\hline Traits & N & & SD & Min & Max & CV \\
\hline ML $(\mathrm{kg})$ & 1409 & 9852.74 & 2055.85 & 4067 & 21913 & 20.86 \\
\hline MM $(\mathrm{kg})$ & 1409 & 349.54 & 68.94 & 134.49 & 607.91 & 19.72 \\
\hline PR $(\mathrm{kg})$ & 1409 & 317.11 & 64.50 & 97.17 & 546.26 & 20.34 \\
\hline
\end{tabular}

Although there exists a potential for higher production, numerous studies conducted in these populations show that it is manifested in different ways since phenotypic manifestation of milk yield is influenced by a great number of factors.

The values determined in this research are significantly higher compared to the values obtained by some other authors. Stanojević et al. (2012a) determined in the population of the first-calf Holstein-Friesian (HF) heifers an average milk yield, milk fat and protein of $7485 \mathrm{~kg}, 263 \mathrm{~kg}$ and 243 $\mathrm{kg}$, respectively, for lactation corrected to 305 days. In a similar population of the first-calf heifers during 2008, even lower milk yield of 7364.86 $\mathrm{kg}$ with $258.75 \mathrm{~kg}$ milk fat and $239.57 \mathrm{~kg}$ protein was recorded in standard lactation (Stanojević et al., 2012b). In contrast to that, Đedović et al. (2003) reported for a 322 days long lactation an average level of milk yield in the first-calf heifers of HF breed of $6194.66 \pm 1354.77 \mathrm{~kg}$ milk and $237.95 \pm 51.58 \mathrm{~kg}$ milk fat. The same authors determined in another research somewhat lower milk yield in total lactation of the first-calf heifers of the same breed which amounted for $5934.25 \mathrm{~kg}$. Similar results were obtained by Beskorovajni (1999) who conducted their research in the firstcalf heifers of Black and White breed and determined the mean milk yield of $5885 \mathrm{~kg}$ with 217.75 $\mathrm{kg}$ milk fat in the standard lactation. In surrounding countries, production results of Holstein-Friesian breed do not correspond to the values determined in this research. In the Former Yugoslav Republic of Macedonia, an average milk yield of $6171 \mathrm{~kg}$ with $249.93 \mathrm{~kg}$ milk fat and $224 \mathrm{~kg}$ protein in total lactation was recorded on few Holstein breed farms (Bunevski et al., 2013), while in Bulgaria the average milk yield in first-calf Holstein-Friesian breed heifers was significantly lower being 4337 kg with 162.20 kg milk fat (Gaidarska, 2009). In the countries with developed cattle breeding a genetic potential of Holstein-Friesian breed cows is well manifested. Zinka et al. (2012) examined the population of the first-calf Holstein-Friesian heifers in the Czech Republic and found high yields of $8353.76 \mathrm{~kg}$ milk, $310.59 \mathrm{~kg}$ milk fat and $271.16 \mathrm{~kg}$ protein, what corresponds to this research. Similar results were also obtained by Heins et al. (2006) who determined the average milk yield in first-calf Holstein heifers in France of 9757 kg with 346 kg milk fat and $305 \mathrm{~kg}$ protein in standard lactation. Results of this research do not correspond with the results of the research by Katok and Yanar (2012) who in standard lactation reported low average yields of milk (3408.17 kg) and milk fat (112.05 kg) in population of first-calf HF heifers in Turkey. On the contrary, Weller and Ezra (2004) determined higher levels of milk yield in relation to the values determined by this research $(10281 \mathrm{~kg}$ milk with $332.08 \mathrm{~kg}$ milk fat and $312,54 \mathrm{~kg}$ protein) in the population of Israeli Holstein in standard lactation.

TABLE 2. Statistical significance of the action of fixed and regression effects and the coefficients of determination of models for milk traits in first-calf heifers

\begin{tabular}{|c|c|c|c|c|c|c|c|c|}
\hline \multirow[b]{2}{*}{ Traits } & \multicolumn{7}{|c|}{ Effects } & \multirow[b]{2}{*}{$\mathrm{R}^{2}$} \\
\hline & Farm & $\begin{array}{l}\text { Share of } \mathrm{H} \\
\text { genes }\end{array}$ & Ration & $\begin{array}{l}\text { Calving } \\
\text { season }\end{array}$ & $\begin{array}{l}\text { Calving } \\
\text { year }\end{array}$ & $\begin{array}{l}\text { Age at } \\
\text { calving }\end{array}$ & $\begin{array}{l}\text { Duration of } \\
\text { lactation }\end{array}$ & \\
\hline $\mathrm{ML}$ & $* * *$ & ns & ns & * & ns & ns & $* * *$ & 0.50 \\
\hline MM & ns & ns & ns & $* *$ & * & * & $* * *$ & 0.55 \\
\hline PR & * & ns & ns & * & ns & ns & $* * *$ & 0.53 \\
\hline
\end{tabular}

$\mathrm{P}<0.001{ }^{* * *} ; \mathrm{P}<0.01{ }^{* *} ; \mathrm{P}<0,05$ *; $\mathrm{P}>0.05$ ns 
A pronounced variability of milk yield is a consequence of the effect of different factors which in their action can be either short or long-lasting. Short effects are manifested in a shorter time interval but they can constantly make changes on the intensity and direction of the action. Long-lasting effects can originate from the surrounding in which individuals realise their production, or they may be a result of the effect of hereditary basis which is unique for each individual. All these effects can act in a certain way and are called systematic effects. On the basis of research results a statistically highly significant $(p<0.001)$ and significant $(p<0.05)$ effects of farm on the yield of milk and the yield of protein in milk were determined, except on the yield of milk fat $(p>0.05)$. Regarding the effect of the farm on the yield of milk and milk protein, the obtained results comply with the results of some studies (Lukač et al., 2014; Stanojević et al., 2012b; Trivunović, 2006) indicating the fact that farm effect on these traits of milk yield was statistically very significant. On the other hand, the results obtained for the farm effect on milk fat yield do not correspond to the conclusions reached by mentioned authors when the effect of this factor on the yield of milk fat is in question.

The results of this research show that the share of Holstein genes in examined population of firstcalf heifers had no statistically significant effect on milk yield parameters ( $p>0.05)$. This does not comply with the research of Nemes et al. (2014) who studied the effect of different share of Holstein genes (from 50 to $100 \%$ ) on the yield of milk and milk fat, and found a statistically significant difference $(p<0.05)$ in milk yield, but a statistically significant difference in the yield of milk fat between the cows with different share of Holstein genes $(p>0.05)$ was not determined. Similar results were also obtained by Perišić et al. (2004) who determined that an increased share of Holstein genes (from 0 to $50 \%$ ) in the first-calf crossbreds of Holstein and Simmental breed had a significant effect $(p<0.01)$ on the production of milk and milk fat.

In this research there were no significant effects of ration in the first stage of lactation on milk yield parameters ( $p>0.05$ ). The concept of nutrition is based on the use of total mixed rations (TMR) based on forage feeds and concentrated feeds with the aim to provide equalised nutrition for cows during a whole year. In certain intervals of the examined period, the composition of totally mixed ration was, to some extent, changed by a lack of some feeds or by a change made in some feeds (molasses or brewer's grain or lack of both feeds simultaneously). However, smaller changes in TMR composition made either by the presence or the lack of mentioned feeds had no statistically significant effect on milk yield parameters ( $p>0.05$ ) (Table 2). The obtained results comply with the results reported in a number of research papers (Penner et al., 2009; Broderik et al, 2008; Miyazawa et al., 2007; Dhiman et al., 2003) showing that the use of molasses or brewer ' grain in milking cow rations had no effect on the milk yield and composition. On the other hand, in some studies (Oba and Gao, 2015; Broderik and Rudloff, 2004; Belibasakis and Tsirgogianni, 1996) a statistically significant effect of the use of mentioned feeds on milk yield parameters was determined.

The year and the season of calving are most often observed through the effects of nutrition and climate elements in certain period in which an animal realises its production. In most cases these effects are observed as unique ones because of interactions existing between them. The results displayed in Table 2 show that calving season had statistically significant effect on the yield of milk and milk proteins $(p<0.05)$ and statistically very significant effect on the yield of milk fat $(p<0.01)$. The results obtained are consistent with a number of studies (Lukač et al., 2014; Stanojević et al., 2012b; Singh et. al., 2001; Gaydarska et al., 2001) in which a significant effect of calving season on the yield of milk, milk fat and protein was determined.

The results of this research show that calving year did not demonstrate a statistically significant effect on the yield of milk and milk protein ( $p>0.05$ ) what is inconsistent with the results obtained by Lukač et al. (2014) and Stanojević et al. (2012b) who report statistically important effect of this factor on the yield of milk and milk protein. On the other hand, calving year had statistically significant effect on the yield of milk fat $(p<0.05)$ confirming the results obtained by Petrović et al. (2009) who also determined statistically significant effect of this factor on the yield of milk fat. 
The effect of age at the first calving can be considered as a capacity of an individual to realise different production in certain age. This research shows (Table 2) that age at first calving had no statistically significant effect on the yield of milk and milk protein ( $p>0.05$ ), which corresponds to the foundings of Krpálková et al. (2014a). On contrary, the obtained results are inconsistent with the conslusions of Etteme et al. (2004) which indicate the existence of a statistically significant difference in milk yield and protein in milk between firstcalf heifers calved in different age. In our research there is a statistically significant difference in the yield of milk fat between first-calf heifers calved at different age $(p<0.05)$ what confirms the results obtained by Etteme et al. (2004).

Taking into account the results presented in Table 2 a highly statistically significant effect of the length of lactation on the yield of milk, milk fat and milk protein $(p<0.001)$ is evident, which corresponds well to the results of Ghavi Hossein - Zadeh (2013). They also reported a statistically significant effect of the length of lactation on these milk yield parameters.

Table 3 displays heritability, heritability error and variances (additive variance, variance error and phenotypic variance) for the traits of first-calf heifers milk yield.

TABLE 3. Heritability $\left(h^{2}\right)$, heritability error (se) and variances (additive variance $-\sigma_{\mathrm{a}}{ }^{2}$, error variance $-\sigma_{\mathrm{e}}{ }^{2}$, phenotypic variance $-\sigma_{\mathrm{p}}{ }^{2}$ ) for milk yield traits in first-calf heifers

\begin{tabular}{l|l|l|l|l}
\hline Traits & $\mathrm{\sigma}_{\mathrm{a}}^{2}$ & $\mathrm{\sigma}_{\mathrm{e}}^{2}$ & $\mathrm{~h}^{2} \pm \mathrm{se}$ & $\mathrm{\sigma}_{\mathrm{p}}^{2}$ \\
\hline $\mathrm{ML}$ & 1188381.97 & 3505953.04 & $0.25 \pm 0.01$ & 4694335.01 \\
\hline $\mathrm{MM}$ & 2299.91 & 3395.39 & $0.40 \pm 0.02$ & 5695.28 \\
\hline $\mathrm{PR}$ & 1779.79 & 2978.10 & $0.37 \pm 0.02$ & 4757.89 \\
\hline
\end{tabular}

Heritability values for the traits of milk yield (ML, MM, PR) of $h^{2}=0.25 ; 0.40 ; 0.37$ presented in Table 3 indicate a mean heritability of these production traits in examined population of Holstein-Friesian first-calf heifers. The results obtained on heritability of the quantity of milk in lactation comply to the results of a number of past studies (Kheirabadi et al., 2013; Konig et al, 2005; Elzo et al., 2004; Weller and Ezra, 2004; Lidauer et al., 2003; Boujenane, 2002; Jakobsen et al., 2002) in which a mean heritability of this trait with heritability coefficients of $h^{2}=0,25 ; 0.35 ; 0.31 ; 0.39 ; 0.30 ; 0.29,0.42$ respectively, was establised as well. On the other hand, the obtained results are inconsistent with a certain number of studies in which a low heritability of this trait was established (Đedović et al., 2013; Stanojević et al., 2012b; Espinoza et al., 2007; Lagar et al., 2005; Strabel and Misztal, 1999) and whose values for heritability coefficients for milk yield are $h^{2}=0.15 ; 0.12 ; 0.10-0.17 ; 0.12-0.18$; 0.16-0.19. Regarding the heritability of the yield of milk fat, results obtained in this research correspond to the research results of the majority of authors (Konig et al., 2005; Elzo et al., 2004; Boujenane, 2002; Jakobsen et al., 2002; Samore et al., 2002) who reported mean values of heritability coefficients for this trait of $\mathrm{h}^{2}=0.38 ; 0.29 ; 0.27$; 0.37 ; 0.34. However, the results obtained in this research regarding heritability of the yield of milk fat do not correspond to a smaller number of studies in which the low heritability of this trait with heritability coefficients for the yield of milk fat of $h^{2}=0,10 ; 0.12$ and 0.16 was established (Đedović et al., 2013; Stanojević et al., 2012b; Strabel and Misztal, 1999).. Heritability value obtained for the yield of protein in milk in our research indicates mean heritability of this trait what is consistent with the research results of majority of authors (Kheirabadi et al., 2013; Konig et al, 2005; Kunaka et al., 2005; Elzo et al., 2004; Lidauer et al., 2003; Jakobsen et al., 2002; Rekaya et al., 1999) who established similar values of heritability coefficients for the yield of milk being $h^{2}=0.25$; $0.34 ; 0.21 ; 0.24 ; 0.23 ; 0.36 ; 0.28$. The obtained results related to the heritability of the yield of protein deviate from the results reported by Stanojević 
et al. (2012b) and by Strabel and Misztal (1999) who confirmed low heritability for this trait heritability values being 0.11 , i.e. 0.15 .

In order to observe genetic and phenotypic correlation, as well as to further study a justification and possibility of combining studied traits in selection of Holstein-Friesian cows the coefficients of genetic and phenotypic correlations shown in Table 4 were used.

TABLE 4. Genetic (above a diagonal) and phenotypic (below a diagonal) correlations of the traits of the milk yield of first-calf heifers

\begin{tabular}{l|c|c|c}
\hline Traits & ML & MM & PR \\
\hline $\mathrm{ML}$ & - & $0.96^{* * *} \pm 0.01$ & $1.00^{* *} \pm 0.00$ \\
\hline $\mathrm{MM}$ & $0.978 * *$ & - & $0.97{ }^{* *} \pm 0.01$ \\
\hline $\mathrm{PR}$ & $0.998 * *$ & $0.98^{\mathrm{g} * *}$ & - \\
\hline
\end{tabular}

$\mathrm{P}<0.01$ **; $\mathrm{P}<0.05$ *; $\mathrm{P}>0.05$ ns

All the values of genetic and phenotypic correlation coefficients of $r_{\mathrm{g}}=0.96$ between $\mathrm{ML}$ and $\mathrm{MM}$ up to $r_{\mathrm{g}}=1.00$ between $M L$ and PR displayed in a previous table, indicate positive, statistically very highly significant $(\mathrm{P}<0.01)$ and complete correlation between ML, MM and PR. A confirmed positive and complete correlation between these traits indicate successful genetic progress possibilities in all three traits by including only one of them in the selection programme. However at the same time can serve as a warning that simultaneous inclusion of all three traits in the selection process could endanger both, a stability of the model itself and exactness of obtained parameters as well as evaluations on the basis of which the selection is being conducted. The results obtained for genetic and phenotypic correlations between the yield of milk and milk fat are consistent with the majority of research results reported in available references (Radinović et al., 2013; Kheirabadi et al., 2013; Gaidarska et al., 2001; Boujenane, 2002; Costa et al., 2000) where positive genetic and phenotypic correlations between the mentioned traits were established with the values of correlation coefficients being $r_{\mathrm{g}}=0.93$; 0.75; 0.95; 0.96; 0.79. In contrast to that, the results of this research regarding genetic correlations between the yield of milk and milk fat are inconsistent with the research results of Stanojević et al. (2013) who report negative correlations between mentioned traits and the values of correlation coefficients of $r_{g}=-0.38$. Positive genetic correlations between the milk yield and the yield of protein in this research correspond with the research of Kheirabadi et al. (2013) who determined a strong and positive relationship between the observed traits $\left(r_{\mathrm{g}}=0.92\right)$.

\section{Conclusion}

According to the results of this research the following, it can be concluded that theeffect of the studied genetic and non-genetic factors on variability of production traits of the first-calf heifers was different. It is however essential to study the statistical significance of their action in order to evaluate the most possible precise heritability variance component for the studied traits.

By applying the animal model which entails the use of kinship matrix the heritability coefficients for the yield of milk, milk fat and milk protein in examined first-calf heifers are evaluated by $h^{2}=0.25 ; 0.40$; 0.37 what indicates a mean heritability of these traits. Genetic and phenotypic correlation between these traits was complete and positive on both levels, with correlation coefficients of $r_{g}=0.96$ between $\mathrm{ML}$ and $\mathrm{MM}$ and up to $\mathrm{r}_{\mathrm{g}}=1.00$ between $\mathrm{ML}$ and $\mathrm{PR}$. 


\section{Fenotipski i genetski parametri osobina mliječnosti prvotelki holštajn-frizijske pasmine}

\section{Sažetak}

Cilj rada bio je utvrditi varijabilnost, nasljednost i povezanost tri proizvodne osobine 1409 prvotelki holštajn-frizijske pasmine; količina mlijeka tijekom laktacije (ML), količina mliječne masti tijekom laktacije (MM) i količina proteina tijekom laktacije (PR). Sukladno postavljenom cilju utvrđeno je da ML, MM i PR statistički značajno variraju $(P<0,01, P<0,05, P<0,001)$ pod utjecajem sezone prvog teljenja i dužine trajanja prve laktacije. Također, ML i PR statistički su značajno varirali $(P<0,01, P<0,001)$ pod utjecajem farme na kojoj su životinje uzgajane, dok su na varijabilnost MM signifikantan utjecaj $(P<0.05)$ imali godina i starost prilikom prvog teljenja. Udio holstein gena i obrok koji su životinje dobivale nisu utjecali $(P>0,05)$ na varijabilnost niti jedne od ispitivanih osobina, dok farma na kojoj su životinje uzgajane nije utjecala $(P>0,05)$ na $M M$, a godina i starost prilikom prvog teljenja nisu imali $(P>0,05)$ statistički značajan utjecaj na ML i PR. Koristeći model životinje, zasnovan na upotrebi matrice srodstva koja je sadržavala 3867 životinja, REML metodologijom ocijenjeni su koeficijenti heritabiliteta za: $M L h^{2}=0,25 ; M_{M} h^{2}=0,40 ; P R h^{2}=0,37$. Utvrđeni koeficijenti genetskih i fenotipskih korelacija ukazivali su na potpunu i pozitivnu povezanost između ovih osobina, s intervalom vrijednosti od $r_{\mathrm{g}}=0,96$ između ML i MM do $r_{\mathrm{g}}=1,00$ između ML i PR.

\section{Ključne riječi: holštajn-frizijske prvotelke, osobine mliječnosti krava, animal model, heritabilitet, genetske korelacije}

\section{References}

1. Belibasakin, N.G., Tsirgogianni, D. (1996): Effects of wet brewers grains on milk yield, milk composition and blood components of dairy cows in hot weather. Animal Feed Science and Technology 57 (3), 175-181. https://doi.org/10.1016/0377-8401(95)00860-8

2. Beskorovajni, R. (1999): Mogućnost unapređenja osobina mlečnosti korišćenjem visokokvalitetnih bikova. Magistarska teza. Poljoprivredni fakultet, Beograd.

3. Boujenane, I. (2002): Estimates of genetic and phenotypic parameters for milk production in maroccan Holsteinfriesian cows. Revue Elev. Med. Vet. Pays Trop. 55 (1), 63-67.

4. Broderick, G.A., Radloff, W.J. (2004): Effect of molasses supplementation on the production of lactating dairy cows fed diets based on alfalfa and corn silage. Journal of Dairy Science 87, 2997-3009. https://doi.org/10.3168/jds.s0022-0302(04)73431-1

5. Broderick, G.A., Luchini, N.D., Reyinal, S.M., Varga, G.A., Ishler, V.A. (2008): Effect on production of replacing dietary starch with sucrose in lactating dairy cows. Journal of Dairy Science 91, 4801-4810.

https://doi.org/10.3168/jds.2008-1480
6. Bunevski, G., Trojacanec, S., Kocevski, D., Trajkovski, G., Krstevski, A., Klincarov, A. (2013): Breeding objektives and economic weights of Holstein cattle in the R. of Macedonia. $23^{\text {rd }}$ International Symposium “New Technologies in Contemporary Animal Production”, Novi Sad. Proceedings, 18-21.

7. Costa, N.R., Blake, W.R., Pollak, J.E., Oltenacu, A.P., Quas, L.R., Searle, R.S. (2000): Genetic analysis of Holstein cattle populations in Brazil and the United States. Journal of Dairy Science 83, 2963-2974. https://doi.org/10.3168/jds.s0022-0302(00)75196-4

8. Dhiman, T.R, Bingham, H.R., Radloff, H.D. (2003): Production response of lactating cows fed dried versus wet brewers' grain in diets with similar dry matter content. Journal of Dairy Science 86, 2914-2921. https://doi.org/10.3168/jds.s0022-0302(03)73888-0

9. Đedović, R., Bogdanović, V., Stanojević, D., Beskorovajni, R., Trivunović, S., Petrović, M., Samolovac, LJ. (2013): The assessment of the selection effects on milk traits in Black-White cattle. $23^{\text {rd }}$ International Symposium "New Technologies in Contemporary Animal Production”, Novi Sad. Proceedings, 18-21. 
10. Đedović, R., Latinović, D., Bogdanović, V., Trifunović, G., Stojić, P., Perišić, P. (2003): Phenotypic and genetic variability of dairy traits of black and white cows. II Symposium of livestock production with international participation. Ohrid, June 18-21, Abstract, pp. 34.

11. Elzo, M.A., Jara, A., Barria, N. (2004): Genetic parameters and trends in the Chilean multibreed dairy cattle population. Journal of Dairy Science 87, 1506-1518. https://doi.org/10.3168/jds.s0022-0302(04)73302-0

12. Etteme, J.F., Santos, J.E.F. (2004): Impact of age at calving on lactation, reproduction, health, and income in firstparity holsteins on commercial farms. Journal of Dairy Science 87, 2730-2742. https://doi.org/10.3168/jds.s0022-0302(04)73400-1

13. Gaidarska, V. (2009): Evaluation of genetic trend of the Bulgarian dairy population. Biotechnology in Animal Husbandry 25 (5-6), 639-644.

14. Gaidarska, V., Krustev, K., Simeonova, S., Ivanov, M. (2001): Influence of environmental and genetic factors on the mik yield and phenotypic and genotypic parameters of milk production in Black - and - White dairy cows in Bulgaria. Biotechnology in Animal Husbandry 17 (1-2), 11-15.

15. Gao, X., Oba, M. (2015): Effect of increasing dietary nonfiber carbohydrate with starch, sucrose, or lactose on rumen fermentation and productivity of lactating dairy cows. Journal of Dairy Science 99, 291-300. https://doi.org/10.3168/jds.2015-9871

16. Ghavi Hossein-Zadeh, N. (2013): Effects of main reproductive and health problems on the performance of dairy cows: a review. Spanish Journal of Agricultural Research 11 (3), 718-735. https://doi.org/10.5424/sjar/2013113-4140

17. Groeneveld, E., Kovač, M., Wang, T. (1990): PEST, a general purpose BLUP package for multivariate prediction and estimation. In: $4^{\text {th }}$ World Congress on Genetics Applied to Livestock Production, Skotland, Edinburgh, Jun 1990., 13, 488-491.

18. Groeneveld, E., Kovac, M., Mielenz, N. (2010): VCE6 User's Guide and Reference Manual. Mariensee, Institute of Farm Animal Genetics, FLI: 125 pp.

19. Heins, B.J., Hansen, L.B., Seykora, A.J. (2006): Production of pure Holsteins Versus Crossbreds of Holstein with Normande, Montbeliarde and Scandinavian Red. Journal of Dairy Science 89, 2799-2804. https://doi.org/10.3168/jds.s0022-0302(06)72356-6

20. Jakobsen, J.H., Madsen, P., Jensen, J., Pedersen, J., Christensen L.G., Soresen D.A. (2002): Genetic parameters for milk production and persistency for Danish Holsteins estimated in random regression models using REML. Journal of Dairy Science 85, 1607-1616. https://doi.org/10.3168/jds.s0022-0302(02)74231-8

21. Katok, N., Yanar, M. (2012): Milk traits and estimation of genetic, phenotypic and environmental trends for milk and milk fat yields in Holstein Friesian cows. International Journal of Agriculture and Biology 14, 311-314.

22. Kheirabadi, K., Alijani, S., Zavidilova, L., Rafat, S.A., Moghaddam, G. (2013): Estimation of genetic parameters for daily milk yields of primiparous Iranian Holstein cows. Archiv Tierzucht 56, (44), 455-456. https://doi.org/10.7482/0003-9438-56-044
23. Kinghorn, B.P. (1994): Pedigree Viewer - a graphical utility for browsing pedigreed data sets. $5^{\text {th }}$ World Congress on Genetics Applied to Livestock Production. Guelph, 7-12 August 1994. 22, 85-86.

24. Konig, S., Nattaphon, C., Langholz, J.H. (2005): Estimation of variance components for production and fertility traits in northern Thai dairy cattle to define optimal breeding strategis. Archiv Tierzucht 3 (48), 233-246. https://doi.org/10.5194/aab-48-233-2005

25. Krpálková, L., Cabrera, V.E., Kvapilík, J., Burdych, J., Crump, P. (2014a): Associations between age at firstcalving, rearing average daily weight gain, herd milkyield and dairy herd production, reproduction, and profitability. Journal of Dairy Science 97, 6573-6582. https://doi.org/10.3168/jds.2013-7497

26. Kunaka, K., Makuza, S.M. (2005): Genetic and environmental trends for milk traits in the Zimbabwean Holstein-fresian population. Pakistan Journal of Biological Sciences 8 (7), 1011-1015. https://doi.org/10.3923/pjbs.2005.1011.1015

27. Lagar, B., Malovrh, Š., Kovač, M. (2005): Multiple triat Analysis of genotype by environment interactions for milk yield traits in Slovenia cattle. Poljoprivreda (Zagreb), 11 (2), 112-118.

28. Latinović, D. (1996): Populaciona genetika i oplemenjivanje domaćih životinja (Praktikum). Univerzitet u Beogradu, Poljoprivredni fakultet Beograd, 1-173.

29. Lidauer, M., Mantysaari, E.A., Stranden, I. (2003): Comparison of test-day models for genetic evaluation of production traits in dairy cattle. Livestock Production Science 79, 73-86. https://doi.org/10.1016/s0301-6226(02)00142-2

3o. Lukač, D., Vidović, V., Nemeš, Ž., Zsolnai, A., Stevanović, M., Bán B. (2014): Association of transferrin genotypes and production traits of Holstein-Friesian cows in Vojvodina. Mljekarstvo, 64 (2), 79-85.

31. Miyazawa, K., Sultana, H., Hirata, T., Kanda, S., Itabashi, H. (2007): Effect of brewer's grain on rumen fermentation, milk production and milk composition in lactating dairy cows. Animal Science Journal 78 (5), 519-526. https://doi.org/10.1111/j.1740-0929.2007.00471.x

32. Nemes, Z., Vidović, V., Lukač, D., Ivanković, A., Grubić, G., Komlósi, I., Gáspárdy, A. (2014): Estimation of nonadditive genetic impacts on lifetime performance through a grading-up breeding program with Holstein-Friesian. Mljekarstvo 64 (4), 261-267. https://doi.org/10.15567/mljekarstvo.2014.0405

33. Palacios Espinoza, A., Espinoza Villavicencio, J.L., Gonzales - Pena, D., Guerra Iglesias, D., De La Pena de Luna, R., Rodriguez Almeida, F. (2007): Estimation of covariance components for the firs four lactations in Holstein cattle according to different models. Zootechnica Trop., 25 (1), 9-18.

34. Penner, G.B., Yu, P., Christensen, D.A. (2009): Effect of replacing forage or concentrate with wet or dry distillers' grains on the productivity and chewing activity of dairy cattle. Animal Feed Science and Technology 153 (1-2), 1-10. https://doi.org/10.1016/j.anifeedsci.2009.05.006 
35. Petrović, M.M, Sretenović, Lj., Aleksić, S., Pantelić, V., Novaković, Ž., Perišić, P., Petrović, D.M. (2009): Investigation of the heritability of phenotipes of fertility and milk performance of Simmental cattle breed in Serbia. Biotechnology in Animal Husbandry 25 (5-6), 285-292. https://doi.org/10.2298/bah0906285p

36. Perišić, P., Skalicki, Z., Mekić, C., Trifunović, G. (2004): Uticaj udela gena crvenog holštajna na reproduktivne i proizvodne osobine prvotelki simentalske rase. Zbornik radova sa XVIII savetovanja agronoma, veterinara, tehnologa i agroekonomista 10 (2), 25-30.

37. Popovac, M., Petrović, M., Radojković, D., Stanojević, D., Miletić, A. Perišić, P. (2014): The assessment of genetic potential in performance tested gilts by means of selection indexes method. Genetika 46 (1), 95-104.

38. Radinović, M., Trivunović, S., Štrbac, Lj., Janković, D., Kučević, D., Korora, J. (2013): Heritability and genetic correlations of milk production traits of first calving Holstein Frisian cow in Vojvodina. $23^{\text {rd }}$ International Symposium "New Technologies in Contemporary Animal Production", Novi Sad. Proceedings, 47-49.

39. Raguž, N., Jovanovac, S., Mészáros, G., Sölkne, R.J. (2014): Linear vs. piecewise Weibull model for genetic evaluation of sires for longevity in Simmental cattle. Mljekarstvo 64 (3), 141-149. https://doi.org/10.15567/mljekarstvo.2014.0301

40. Rekaya, R., Carabano, M.J., Toro, M.A. (1999): Use of test day yields for the genetic evaluation of production traits in Holstein-Friesian cattle. Livestock Production Science 57, 203-217. https://doi.org/10.1016/s0301-6226(98)00181-x

41. Samoré, A.B., Boettcher, P..., Jamrozik, J., Bagnato, A., Groen, A.F. (2002): Genetic parameters for production traits and somatic cell scores estimated with a multiple trait random regression model in Italian Holsteins. Proceedings of the $7^{\text {th }}$ WCGALP. 01-07, Montpellier, France.

42. SAS Inst. Inc. (2010): SAS/STAT ${ }^{\circledR} 9.3 \_M 1$ User's Guide. Cary, NC.

43. Singh, K., Sangwan, M.L., Dalal, D.S (2001): Estimation of Genetic and Environmental Trends in Hariana Cattle. Asian Australasian Journal of Animal Sciences. 15 (1), 7-14. https://doi.org/10.5713/ajas.2002.7
44. Snidikor, G., Cochran, W. (1971): Statistical Methods (Book). Iowa State University Press.

45. Stanojević, D., Đedović, R., Perišić, P., Beskorovajni, R., Popovac, M. (2013): Fenotipska i genetska povezanost osobina mlečnosti u prve tri uzastopne laktacije crnobelih krava. Zbornik radova sa XXVII savetovanja agronoma, veterinara, tehnologa i agroekonomista 19 (3-4), 17-24.

46. Stanojević, D., Đedović, R., Bogdanović, V., Popovac. M., Perišić, P., Beskorovajni, R. (2012b): Fenotipska i genotipska varijabilnost i povezanost osobina mlečnosti prvotelki crnobele rase. Zbornik radova sa XXVI savetovanja agronoma, veterinara, tehnologa i agroekonomista 18 (3-4), 15-22.

47. Stanojević, D., Đedović, R., Popovac, M., Perišić, P., Samolovac, Lj. (2012a): Correlations between the breeding value and ranking of bulls the milk yield traits in the first calf heifers of the black and white breed. Proceedings of the First International Symposium on Animal Science, Book I, 280-285.

48. Strabel, T., Misztal, I. (1999): Genetic parameters for first and second lactation milk yields of Polish black and white cattle with random regression test-day models. Journal of Dairy Science 82, 2805-2810. https://doi.org/10.3168/jds.s0022-0302(99)75538-4

49. Trivunović, S. (2006): Genetski trend prinosa mleka i mlečne masti u progenom testu bikova za veštačko osemenjavanje. Doktorska disertacija. Poljoprivredni fakultet, Novi Sad.

50. Weller, J.I., Ezra, E. (2004): Genetic Analysis of the Izrael Holstein Dairy Cattle Population for Production and Nonproduction Traits with a Multitrait Animal Model. Journal of Dairy Science 87, 1519-1527. https://doi.org/10.3168/jds.s0022-0302(04)73303-2

51. Zink, V., Lassen, J., Štipkova, M. (2012): Genetic parameters for female fertility and milk production traits in first-parity Czech Holstein cows. Czech Journal of Animal Science 57 (3), 108-114. https://doi.org/10.17221/5562-cjas 